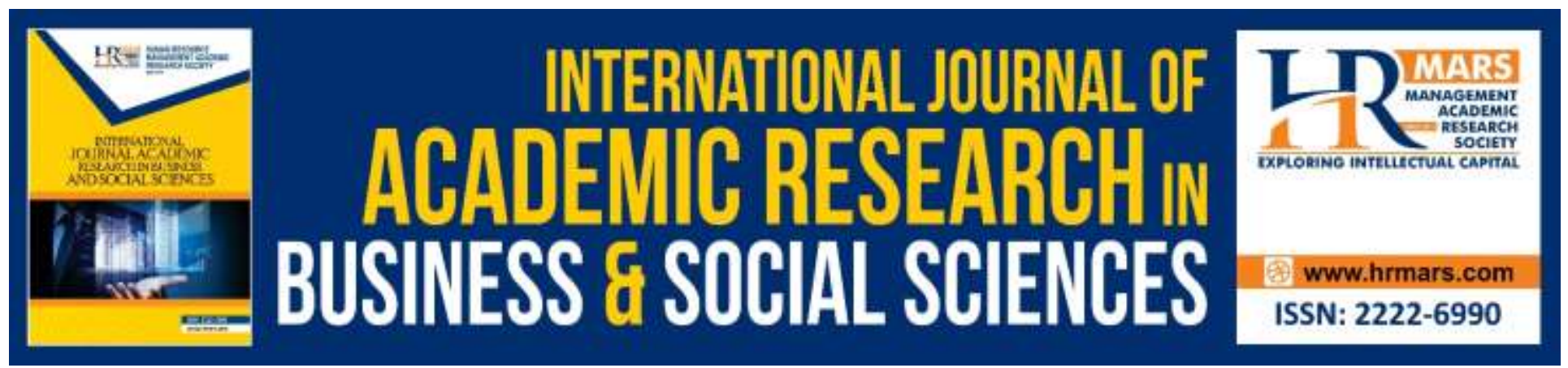

\title{
Application of Strategic Management Information System (SMIS) in the Ministry of Interior, UAE: Issues and Challenges
}

Yaser Alraei Alnekhaira Buti Alshams, Joseph Adaikalam, Asif Mahbub Karim, Oo Yu Hock, Mohammad Imtiaz Hossain

To Link this Article: http://dx.doi.org/10.6007/IJARBSS/v10-i2/6934

DOI:10.6007/IJARBSS/v10-i2/6934

Received: 09 January 2020, Revised: 28 January 2020, Accepted: 02 February 2020

Published Online: 19 February 2020

In-Text Citation: (Alshams et al., 2020)

To Cite this Article: Alshams, Y. A. A. B., Adaikalam, J., Karim, A. M., Hock, O. Y., \& Hossain, M. I. (2020).

Application of Strategic Management Information System (SMIS) in the Ministry of Interior, UAE: Issues and Challenges. International Journal of Academic Research in Business and Social Sciences, 10(2), 346-361.

\section{Copyright: (C) 2020 The Author(s)}

Published by Human Resource Management Academic Research Society (www.hrmars.com)

This article is published under the Creative Commons Attribution (CC BY 4.0) license. Anyone may reproduce, distribute, translate and create derivative works of this article (for both commercial and non-commercial purposes), subject to full attribution to the original publication and authors. The full terms of this license may be seen

at: http://creativecommons.org/licences/by/4.0/legalcode

Vol. 10, No. 2, 2020, Pg. 346 - 361

http://hrmars.com/index.php/pages/detail/IJARBSS

JOURNAL HOMEPAGE

Full Terms \& Conditions of access and use can be found at http://hrmars.com/index.php/pages/detail/publication-ethics 


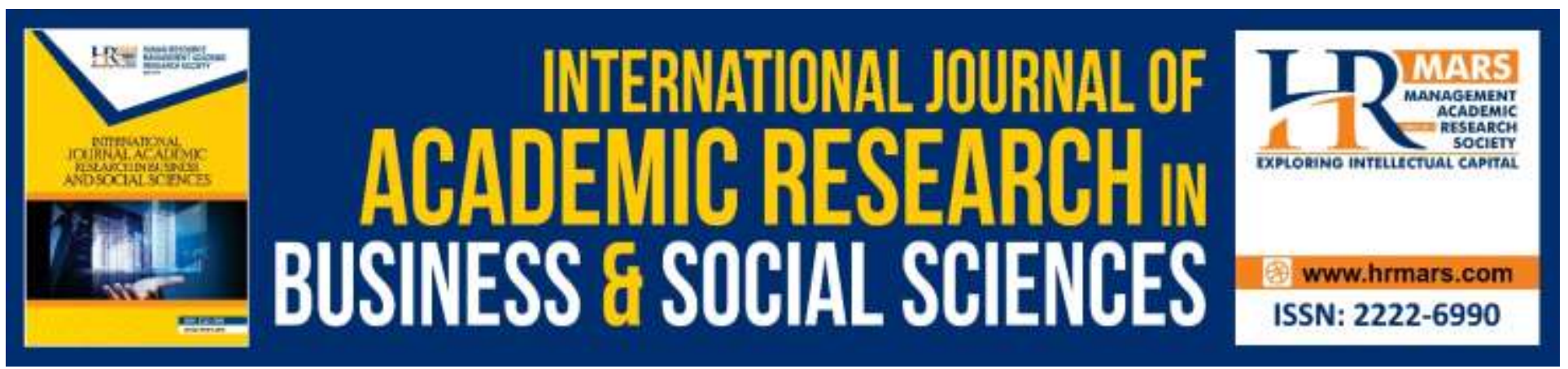

\title{
Application of Strategic Management Information System (SMIS) in the Ministry of Interior, UAE: Issues and Challenges
}

\author{
${ }^{1}$ Yaser Alraei Alnekhaira Buti Alshams, ${ }^{2}$ Professor Joseph \\ Adaikalam, ${ }^{3} \mathrm{Dr}$ Asif Mahbub Karim, ${ }^{4} \mathrm{Dr}$ Oo Yu Hock, ${ }^{5}$ Mohammad \\ Imtiaz Hossain
}

${ }^{1} \mathrm{PhD}$ Research Fellow, Binary University of Management \& Entrepreneurship, Malaysia, ${ }^{2}$ Founder and Executive Chairman, Binary University of Management \& Entrepreneurship, Malaysia, ${ }^{3}$ Dean \& Associate Professor, Binary Graduate School, Binary University of Management \& Entrepreneurship,

Malaysia, ${ }^{4}$ Professor, Asia e University (AeU), Malaysia, ${ }^{5} \mathrm{MSc}$ in Business Economics, Universiti

Putra Malaysia, Malaysia

\begin{abstract}
The purpose of this paper is to present and describe SMIS implementation challenges or problems as well as identifying the key issues to achieve successful implementation. Moreover, this research seeks to explain the implementation effects and consequences which impact the organization and its processes. We investigate the key challenges faced for implementing SMIS in the Ministry of Interior, UAE. Quantitative methodology used and structured questionnaire was imployed.150 respondents were participated in this study and data was analyzed by using SPSS V.19.

The findings show that budgetary, infrastructural and human resource capabilities have significant impact on the performance of SMIS. It is recommended to invest in technology development and taking initiatives to enhance skill of employee. Increase awareness at every level of the management, from the grass root level should be practiced as to make all aware that such a strategic management information system exists in the ministry of interior. Better regulatory observation needed to be adhered to monitor the information system and adhere to compliance issues. Training facilities by both in house and external trainers required on the latest software and application of strategic management information system.
\end{abstract}

Keywords: Strategic Management, Information System, Implementation, Public Sector, UAE

\section{Introduction}

Government is, to some extent, the biggest public information owner and distributes vast amounts of information used by all segments of the public. In many developing countries, it is often the only 
producer of relevant economic and social information. Making information accessible to the public has become an important part of service to the citizen. Experience among industrial and newly industrializing countries show that, public policies which enable efficient private access to public data. And they are key ingredient to achieve organizational competitiveness. Moving information elements efficiently is one of the major challenges in the age of digital disruption. It is also one of the primary impediments to making even greater use of communications and computer capabilities in the public sector.

Numerous types of information such as technical, statistical, scientific, and reference may be stored and disseminated electronically. For example, national census statistical reports could be made available on optical disks. Electronic and network distribution of government documents and increasing public access to government data are being developed very fast in industrial countries, such as information systems that let users search, locate, view and download government reports, studies, computer software, data files and databases, and CD-ROMs, with information being updated regularly. There is no doubt that effective use of SMIS can make governments work efficiently, increase productivity, and cost effective.

A study by Mahmoudi (2009) established that SMIS plays a major role in giving organizations a competitive edge and also improving the performance through such means as; allowing the innovation of unique products which at times lead to first mover advantage, reduction in operation costs by increasing efficiency, developing strategic alliances with industry stakeholders including; customers, suppliers, consultants and other companies. In another study (Alshamsi, Hock, Karim, \& Hossain, 2019) explained briefly about the importance of SMIS in public sector. They mentioned that SMIS endow management to act, respond construct, support, and compound upper hand.

Another example, an integrated revenue management information system will improve tax data available to collection employees in the field; revenue officers will be able to receive cases more quickly and depose of them sooner. A system using distributed computing architecture to automate and modernize tax collection process will enable the treasury department to collect tax more efficiently, which is, of course, a benefit to all government agencies. It can be said that governance and public administration cannot be productive, effective and efficient without the support of modern information technology. The use of information technology has been an absolute requirement for public administration and management development.

The UAE Cabinet released the UAE Vision 2021 the slogan of which is 'We want to be among the best countries in the world by 2021'. To achieve the vision UAE Government decided to transform into a smart environment that is characterized by the following a) The Government transitions to smart devices as the primary access channel, b)increased focus is placed on smart services that are predictive and pervasive, c) There is advanced use of Secure Identity across federal and local government entities, c) The infrastructure is integrated at a national level.

The crucial initiative with which it has started to achieve its objective is to formulate a comprehensive framework General Secretariat of the Executive Council (GSEC)which comprises strategic planning and government performance management. This GSEC framework has been applied to 32 government entities in Abu Dhabi. The GSEC works loosely with government bodies to apply a new planning methodology, the Balanced Scorecard. In order to assist government organizations to achieve their ambitious goals and to bring about the Emirate vision, it coordinates with these 
INTERNATIONAL JOURNAL OF ACADEMIC RESEARCH IN BUSINESS AND SOCIAL SCIENCES Vol. 10, No. 2, Feb, 2020, E-ISSN: 2222-6990 @ 2020 HRMARS

organizations to develop Abu Dhabi's policies and strategic plans and supports their active implementation (Fakhrah, 2017).

Abu Dhabi Accountability Authority (ADAA) started its journey to promote high standards of governance, accountability and transparency to ensure that funds dispensed by public entities, achieve desired goals effectively, efficiently, economically, and ethically. Support public entities in enhancing their performance and improve the quality of data used by decision makers (ADAA, 2008). Still it is working for proper implementation of the Strategic Management Information System in public sector of UAE (ADAA, 2017)

A study conducted by World Bank (2014) on the performance of government institutions in GCC countries identified that $73 \%$ of the government institutions were underperforming due to inappropriate technology adopted.

Since Ministry of Interior considered as one of the important ministry of any government, the strategic system integration and development and digitalization is essential for achieving overall goal. There have no study on this issue in the context of UAE. So this study aims to fill up this gap.

\section{Literature Review}

The National plan strategy was developed utilizing some approaches that starts with assessing the current situation of UAE Government and builds on it to establish the Smart Government Operating model, Roadmap and Transformation Measures. Several steps will be applied. 1) Assess Current State, 2) Refine Strategy, 3) Create Roadmap, 4) Develop Transformation Measurement.

Stakeholder engagement and collaboration from federal and local entities contributed to the National Plan. Discussions were guided as well by UAE's Smart Government Maturity Model, which shed light on all relevant aspects and details to be assessed for each interviewed stakeholder. Then, the National Plan was developed in alignment with the UAE National Guidance that is predicted on UAE Vision 2021, UAE National Agenda and ICT 2021 Strategy. In addition to that, interviewed Government entities smart government plans helped inform and direct the National Plan for UAE Smart Government Goals. The project team engaged key stakeholders to help refine and clarify the National Plan's vision and mission statements. Initiatives were sequenced based on three logical criteria-Existing, Dependencies, and Capacity/Criticality-as well as a number of assumptions to ensure initiative charters were sequenced into an achievable action plan and roadmap. Ensuring alignment of initiatives to the National Plan is paramount to the overall success of the Smart Government transformation. To support alignment, a smart performance management framework was developed to guide the definition of key performance indicators (KPI) for UAE's Smart Government initiatives at strategic and operational levels. Strategic KPIs are stated under the Transformation Measurement-Strategic Measures section of this document. Operational KPIs will be developed as initiatives progress through the procure, design, build, implement, and operate phases.

Abu Dhabi introduced the Onwani (my address) system. Onwani is Abu Dhabi's smart addressing system. CityGuard is a free app from Abu Dhabi Government. The app is available for BlackBerry, Android and iOS platforms. Free Wi-Fi is available to taxi passengers in Abu Dhabi. The 5-D control room would be the world's largest room which will be used to follow-up the process of transforming Dubai into a smart city. I-Dubai would provide information relating to the services of the municipality. Environment-friendly electric bikes "Makani" for patrolling. The mPay app is available on iTunes and 
INTERNATIONAL JOURNAL OF ACADEMIC RESEARCH IN BUSINESS AND SOCIAL SCIENCES Vol. 10, No. 2, Feb, 2020, E-ISSN: 2222-6990 ¿ 2020 HRMARS

Google Play. Smart addressing system in aach building would have a QR code which would be embedded with details relating to its location. The ability to locate the buildings would be accurate to one metre (Al-Khalifa, Hessa, 2018).

\section{SMIS Problem Areas}

Each organization's SMIS procedure is probably going to have issues. These issues ought to be perceived and made arrangements for in the beginning a time of the vital IS/IT arranging. Willcocks (2003) discovered Inappropriate measures, Budgeting practice disguises full costs, Understanding human and authoritative costs, Understanding thump on costs, Overstating costs, Neglecting 'immaterial' advantages, Not completely examining hazard, Failure to dedicate assessment time and push to a noteworthy capital, Failure to consider time-size of likely advantages discovered Involvement and duty of senior management, Linking IS to business objectives, Rapid difference in technology, Lack of survey of the IS key designs and assessment of got comes about.

Measuring benefits Nature of business, Difficulty in selecting, Political clashes, Existing IT speculation, User instruction assets, Doubts about advantages, Telecommunications issues, Middle management mentalities and Senior management attitudes, Technology lingering behind necessities. (Alshamsi, Hock, Karim, \& Hossain, 2019) noted several problems and issues regarding implementing SMIS.

As indicated by Earl (2002) Resource obliges Not completely actualized, Lack of best management, Length of time included, Poor client IS connections (All worries assembled into three classes: strategy concerns, usage, and process concerns) The issues of portraying business process for exchange to IT wrong mechanization.

The accompanying legitimate issues may impact SMIS in a few organizations (Ward and Griffiths, 1996; Hubbard et al., 1996;): limitations on e-business, paperless exchanging issues, PC based misrepresentation issues, presentation of a few types of "Information Protection Acts', changes in granting harms approach; and patent arrangement. Lack of support from top management also make the strategic IS planning a priority.

\section{Conceptual Framework}

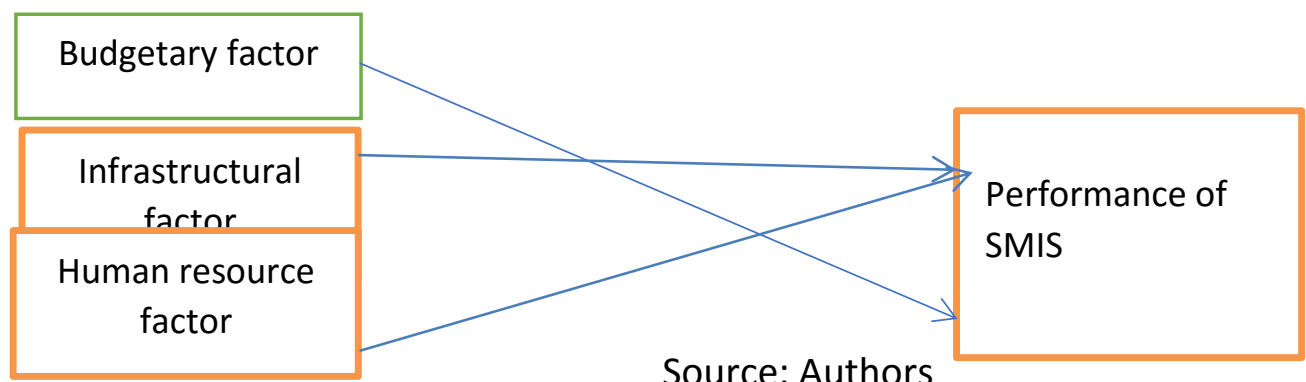

\section{Objectives}

1. To examine the Performance of Strategic Management Information System in the Ministry of Interior, UAE

2. To examine the impact of Budgetary factor on implementing Strategic Management Information System in Ministry of Interior, UAE 
INTERNATIONAL JOURNAL OF ACADEMIC RESEARCH IN BUSINESS AND SOCIAL SCIENCES Vol. 10, No. 2, Feb, 2020, E-ISSN: 2222-6990 @ 2020 HRMARS

3. To examine the impact of Infrastructural factor on implementing Strategic Management Information System in Ministry of Interior, UAE

4. To examine the impact of human resource factor on implementing Strategic Management Information System in Ministry of Interior, UAE

5. To make recommendation to improve operation of Strategic Management Information System in the Ministry of Interior, UAE

\section{Methodology}

Research methodology comprises of a guide which features the principles and proposes strategies that scientists utilize to render their work open to research, scrutinize, replication, reiteration, and additionally adjustment and to pick investigate techniques. A quantitative methodology is used to assess the trust of the system that leads to its adoption. The research was conducted using selfadministered questionnaires. A structured questionnaire was prepared after consultation guides, experts in the field, and after going through review of relevant literature. The questionnaire designed in this study is 5 Likert Scale. Questions of Independent variables were utilizing on a Likert scale ranging from $1=$ strongly disagree to $6=$ strongly agree and performance of SMIS use $5=$ much better off, 4= somehow better off; 3 =about the same; 2 =somehow worse off; 1 = much worse off.

SPSS used to analyse the data. Five out of the seven Emirates were selected for the supervision of the questionnaires. The five were Abu Dhabi, Dubai, Shaijah, Ajman and Ras Al-Khaima. The five were selected because they were geographically contiguous to each other and they had the largest concentration of population in the UAE.

In total, 193 questionnaires were administered to the members of the public. To make sure that the questionnaires got to only those who were literate and well informed enough to answer the questions, the questionnaires were administered in front of the ministry concerned in each of the selected Emirates patronised by the educated class across the linguistic divides of the UAE. Out of the 193 questionnaires that were administered 165 were returned. From the numbers returned, 15 were either incomplete or improperly filled which rendered them useless for analysis. Therefore, only 150 were considered for analysis.

\section{Data Analysis and Findings}

Demographic Information

Table 1: Gender

\begin{tabular}{|ll|l|l|l|l|}
\hline & & & & & Cumulative \\
& & Frequency & Percent & Valid Percent & Percent \\
\hline Valid & male & 63 & 42.0 & 42.0 & 42.0 \\
& female & 87 & 58.0 & 58.0 & 100.0 \\
& Total & 150 & 100.0 & 100.0 & \\
\hline
\end{tabular}

The results show that $42.0 \%$ of respondents were male while $58.0 \%$ of respondents were female. From this study it was concluded that the number of males was high compared to the number of females participated in the Ministry of Interior's Strategy. 
INTERNATIONAL JOURNAL OF ACADEMIC RESEARCH IN BUSINESS AND SOCIAL SCIENCES Vol. 10, No. 2, Feb, 2020, E-ISSN: 2222-6990 @ 2020 HRMARS

Table 2: Age of respondents

\begin{tabular}{|c|c|c|c|c|c|}
\hline & & Frequency & Percent & Valid Percent & $\begin{array}{l}\text { Cumulative } \\
\text { Percent }\end{array}$ \\
\hline \multirow[t]{5}{*}{ Valid } & less than 30 years & 19 & 12.7 & 12.7 & 12.7 \\
\hline & less than 40 years & 49 & 32.7 & 32.7 & 45.3 \\
\hline & less than 50 years & 61 & 40.7 & 40.7 & 86.0 \\
\hline & more than 50 years & 21 & 14.0 & 14.0 & 100.0 \\
\hline & Total & 150 & 100.0 & 100.0 & \\
\hline
\end{tabular}

The table presents the age of the respondents, from the table above the results show that $12.7 \%$ of the respondents were less than 30 years old, $32.7 \%$ were less than 40 years old, $40.7 \%$ were less than 50 years and $14.0 \%$ were more than 50 years old. This shows that majority of respondents were within the age group of 40 to 49 years (40.7\%). This situation the majority of the respondents were medium aged and experienced.

Table 3: Experience

\begin{tabular}{|ll|l|l|l|l|}
\hline & & & & Cumulative \\
& & Frequency & Percent & Valid Percent & Percent \\
\hline Valid & less than 5 years & 53 & 35.3 & 35.3 & 35.3 \\
& less than 10 years & 64 & 42.7 & 42.7 & 78.0 \\
& more than 10 years & 33 & 22.0 & 22.0 & 100.0 \\
Total & 150 & 100.0 & 100.0 & \\
\hline
\end{tabular}

The table above represents the experience of the respondents. 35.3\% of the respondents had less than 5 years working experience, $42.7 \%$ had less than 10 years working experience and $22.0 \%$ had for more than 10 years working experience.

\section{Budgetary Factor}

Table 4: Organization should provide sufficient budget for SMIS operations.

\begin{tabular}{|ll|l|l|l|l|}
\hline & & & & Cumulative \\
& & Frequency & Percent & Valid Percent & \begin{tabular}{l} 
Percent \\
\hline Valid
\end{tabular} strongly disagree \\
Disagree & 1 & .7 & .7 & .7 \\
& 8 & 5.3 & 5.3 & 6.0 \\
Neutral & 9 & 6.0 & 6.0 & 12.0 \\
Agree & 54 & 36.0 & 36.0 & 48.0 \\
strongly agree & 78 & 52.0 & 52.0 & 100.0 \\
Total & 150 & 100.0 & 100.0 & \\
\hline
\end{tabular}


INTERNATIONAL JOURNAL OF ACADEMIC RESEARCH IN BUSINESS AND SOCIAL SCIENCES Vol. 10, No. 2, Feb, 2020, E-ISSN: 2222-6990 @ 2020 HRMARS

Table 5: Organization should ensure proper allocation of the budget for SMIS implementation

\begin{tabular}{|ll|l|l|l|l|}
\hline & Frequency & Percent & Valid Percent & $\begin{array}{l}\text { Cumulative } \\
\text { Percent }\end{array}$ \\
\hline Valid & strongly disagree & 1 & .7 & .7 & .7 \\
& Disagree & 3 & 2.0 & 2.0 & 2.7 \\
Neutral & 6 & 4.0 & 4.0 & 6.7 \\
Agree & 83 & 55.3 & 55.3 & 62.0 \\
strongly agree & 57 & 38.0 & 38.0 & 100.0 \\
Total & 150 & 100.0 & 100.0 & \\
\hline
\end{tabular}

Table 6: Organization should invest in technological development for SMIS implementation

\begin{tabular}{|c|c|c|c|c|c|}
\hline & & Frequency & Percent & Valid Percent & $\begin{array}{l}\text { Cumulative } \\
\text { Percent }\end{array}$ \\
\hline \multirow[t]{5}{*}{ Valid } & Disagree & 2 & 1.3 & 1.3 & 1.3 \\
\hline & Neutral & 19 & 12.7 & 12.7 & 14.0 \\
\hline & Agree & 78 & 52.0 & 52.0 & 66.0 \\
\hline & strongly agree & 51 & 34.0 & 34.0 & 100.0 \\
\hline & Total & 150 & 100.0 & 100.0 & \\
\hline
\end{tabular}

Table 7: Organization should invest in skill development for SMIS implementation

\begin{tabular}{|c|c|c|c|c|c|}
\hline & & Frequency & Percent & Valid Percent & $\begin{array}{l}\text { Cumulative } \\
\text { Percent }\end{array}$ \\
\hline \multirow[t]{6}{*}{ Valid } & strongly disagree & 1 & .7 & .7 & .7 \\
\hline & Disagree & 2 & 1.3 & 1.3 & 2.0 \\
\hline & Neutral & 5 & 3.3 & 3.3 & 5.3 \\
\hline & Agree & 98 & 65.3 & 65.3 & 70.7 \\
\hline & strongly agree & 44 & 29.3 & 29.3 & 100.0 \\
\hline & Total & 150 & 100.0 & 100.0 & \\
\hline
\end{tabular}

Responds indicates that majorities are agreed that organization should have budget, should invest in technological and skill development for implementing SMIS. 
INTERNATIONAL JOURNAL OF ACADEMIC RESEARCH IN BUSINESS AND SOCIAL SCIENCES Vol. 10, No. 2, Feb, 2020, E-ISSN: 2222-6990 (C) 2020 HRMARS

\section{Infrastructural Factors}

Table 8: The organizational structure simplifies the exchange of knowledge and information.

\begin{tabular}{|ll|l|l|l|l|}
\hline & & & & Cumulative \\
& & Frequency & Percent & Valid Percent & Percent \\
\hline Valid & Disagree & 3 & 2.0 & 2.0 & 2.0 \\
& Neutral & 13 & 8.7 & 8.7 & 10.7 \\
& Agree & 58 & 38.7 & 38.7 & 49.3 \\
& strongly agree & 76 & 50.7 & 50.7 & 100.0 \\
Total & 150 & 100.0 & 100.0 & \\
\hline
\end{tabular}

Table 9: The organizations infrastructure and cultural environment encourage the use of strategic management information system.

\begin{tabular}{|ll|l|l|l|l|}
\hline & & & & Cumulative \\
& & Frequency & Percent & Valid Percent & Percent \\
\hline Valid & Disagree & 2 & 1.3 & 1.3 & 1.3 \\
& Neutral & 9 & 6.0 & 6.0 & 7.3 \\
& Agree & 74 & 49.3 & 49.3 & 56.7 \\
& strongly agree & 65 & 43.3 & 43.3 & 100.0 \\
& Total & 150 & 100.0 & 100.0 & \\
\hline
\end{tabular}

Table 10: High management believable in the strategic management information system importance.

\begin{tabular}{|ll|l|l|l|l|}
\hline & & & & Cumulative \\
& & Frequency & Percent & Valid Percent & Percent \\
\hline Valid & Strongly disagree & 1 & .7 & .7 & 7 \\
& Disagree & 2 & 1.3 & 1.3 & 2.0 \\
& Neutral & 17 & 11.3 & 11.3 & 13.3 \\
Agree & 66 & 44.0 & 44.0 & 57.3 \\
strongly agree & 64 & 42.7 & 42.7 & 100.0 \\
Total & 150 & 100.0 & 100.0 & \\
\hline
\end{tabular}

Table 11: The procedures and roles that simplify the work of strategic management information system.

\begin{tabular}{|ll|l|l|l|l|}
\hline & & Frequency & Percent & Valid Percent & Cumulative Percent \\
\hline Valid & Disagree & 3 & 2.0 & 2.0 & 2.0 \\
& Neutral & 17 & 11.3 & 11.3 & 13.3 \\
& Agree & 71 & 47.3 & 47.3 & 60.7 \\
strongly agree & 59 & 39.3 & 39.3 & 100.0 \\
Total & 150 & 100.0 & 100.0 & \\
\hline
\end{tabular}


INTERNATIONAL JOURNAL OF ACADEMIC RESEARCH IN BUSINESS AND SOCIAL SCIENCES Vol. 10, No. 2, Feb, 2020, E-ISSN: 2222-6990 (C) 2020 HRMARS

The outcomes proves from the response that organizational infrastructure simplify the exchange of information, encourage of usage of IT. Besides that, top managements' believe, work procedure also crucial to implement SMIS in organization.

\section{Human Resource Factor}

Table 12: Organizations commitment to train and qualify employees to use strategic Management information system.

\begin{tabular}{|ll|l|l|l|l|}
\hline & & & & Cumulative \\
& Frequency & Percent & Valid Percent & Percent \\
\hline Valid & Disagree & 7 & 4.7 & 4.7 & 4.7 \\
& Neutral & 16 & 10.7 & 10.7 & 15.3 \\
& Agree & 38 & 25.3 & 25.3 & 40.7 \\
& strongly agree & 89 & 59.3 & 59.3 & 100.0 \\
Total & 150 & 100.0 & 100.0 & \\
\hline
\end{tabular}

Table 13: Adopting computer usage capability as criteria in employment selection process.

\begin{tabular}{|ll|l|l|l|l|}
\hline & & & & Cumulative \\
& & Frequency & Percent & Valid Percent & Percent \\
\hline Valid & Strongly disagree & 1 & .7 & .7 & 7 \\
& Disagree & 3 & 2.0 & 2.0 & 2.7 \\
& Neutral & 9 & 6.0 & 6.0 & 8.7 \\
Agree & 60 & 40.0 & 40.0 & 48.7 \\
& strongly agree & 77 & 51.3 & 51.3 & 100.0 \\
Total & 150 & 100.0 & 100.0 & \\
\hline
\end{tabular}

Table 14: Having specialists in strategic management information system.

\begin{tabular}{|ll|l|l|l|l|}
\hline & & & & Cumulative \\
& & Frequency & Percent & Valid Percent & Percent \\
\hline Valid & Strongly disagree & 2 & 1.3 & 1.3 & 1.3 \\
& Disagree & 2 & 1.3 & 1.3 & 2.7 \\
& Neutral & 14 & 9.3 & 9.3 & 12.0 \\
Agree & 54 & 36.0 & 36.0 & 48.0 \\
strongly agree & 78 & 52.0 & 52.0 & 100.0 \\
Total & 150 & 100.0 & 100.0 & \\
\hline
\end{tabular}

Above results shoes that organizational commitment to develop employees' skill, computer usage capability and having specialist are significantly important for implementing SMIS in the organization. 
INTERNATIONAL JOURNAL OF ACADEMIC RESEARCH IN BUSINESS AND SOCIAL SCIENCES Vol. 10, No. 2, Feb, 2020, E-ISSN: 2222-6990 @ 2020 HRMARS

\section{Performance of SMIS}

Table 15: Introduce the support and information for the customer.

\begin{tabular}{|ll|l|l|l|l|}
\hline & & & & Vumulative \\
& & Frequency & Percent & Valid Percent & $\begin{array}{l}\text { Cumcent } \\
\text { Percent }\end{array}$ \\
\hline Valid & much worse off & 2 & 1.3 & 1.3 & 1.3 \\
& somehow worse off & 3 & 2.0 & 2.0 & 3.3 \\
& about the same & 15 & 10.0 & 10.0 & 13.3 \\
somehow better off & 47 & 31.3 & 31.3 & 44.7 \\
much better off & 83 & 55.3 & 55.3 & 100.0 \\
Total & 150 & 100.0 & 100.0 & \\
\hline
\end{tabular}

A total of 150 questionnaires were distributed and all were filled and returned giving a response rate of $100 \%$. According to the table 15, 1.3\% (2) of the respondents revealed that introduce the support and information for the customer was much worse off, $2 \%(3)$ of the respondents revealed as somehow worse off, $10 \%$ (15) said as about the same, $31.3 \%$ (47) considered as somehow better off and $55.3 \%(83)$ revealed as much better off.

Table 16: Speed the achieving required works.

\begin{tabular}{|ll|l|l|l|l|}
\hline & & & & Cumulative \\
& & Frequency & Percent & Valid Percent & $\begin{array}{l}\text { Percent } \\
\text { Valid }\end{array}$ much worse off \\
& 1 & .7 & .7 & .7 \\
& somehow worse off & 1 & .7 & .7 & 1.3 \\
& about the same & 18 & 12.0 & 12.0 & 13.3 \\
& somehow better off & 68 & 45.3 & 45.3 & 58.7 \\
much better off & 62 & 41.3 & 41.3 & 100.0 \\
Total & 150 & 100.0 & 100.0 & \\
\hline
\end{tabular}

According to the table $16, .7 \%$ (1) of respondents revealed that speed the achieving required works was much worse off, .7\% (1) of respondents were somehow worse off, $12.0 \%$ (18) of respondents were about the same $45.3 \%$ (68) of respondents said Somehow, better off and $41.3 \%$ (62) of respondents were much better off.

Table 17: Increasing the degree of authority delegation.

\begin{tabular}{|ll|l|l|l|l|}
\hline & Frequency & Percent & Valid Percent & Cumulative Percent \\
\hline Valid & somehow worse off & 2 & 1.3 & 1.3 & 1.3 \\
& about the same & 13 & 8.7 & 8.7 & 10.0 \\
& somehow better off & 70 & 46.7 & 46.7 & 56.7 \\
much better of & 65 & 43.3 & 43.3 & 100.0 \\
Total & 150 & 100.0 & 100.0 & \\
\hline
\end{tabular}


INTERNATIONAL JOURNAL OF ACADEMIC RESEARCH IN BUSINESS AND SOCIAL SCIENCES Vol. 10, No. 2, Feb, 2020, E-ISSN: 2222-6990 @ 2020 HRMARS

According to the table17, 1.3\% (2) of the respondents revealed that increasing the degree of authority delegation was somehow worse off, $8.7 \%$ (13) said as about the same, $46.7 \%$ (70) considered as somehow better off and $43.3 \%(65)$ revealed as much better off.

Table 18: Accelerate the process of deliver the products and services to customers.

\begin{tabular}{|c|c|c|c|c|c|}
\hline & & Frequency & Percent & Valid Percent & $\begin{array}{l}\text { Cumulative } \\
\text { Percent }\end{array}$ \\
\hline \multirow[t]{6}{*}{ Valid } & much worse off & 4 & 2.7 & 2.7 & 2.7 \\
\hline & somehow worse off & 5 & 3.3 & 3.3 & 6.0 \\
\hline & about the same & 19 & 12.7 & 12.7 & 18.7 \\
\hline & somehow better off & 63 & 42.0 & 42.0 & 60.7 \\
\hline & much better off & 59 & 39.3 & 39.3 & 100.0 \\
\hline & Total & 150 & 100.0 & 100.0 & \\
\hline
\end{tabular}

According to the table above, $2.7 \%(4)$ of respondents revealed that accelerate the process of deliver the products and services to customers was much worse off, 3.3\%(5) of respondents were somehow worse off, $12.7 \%(19)$ of respondents said about the same, $42.0 \%(63)$ of respondents were somehow better off and $39.3 \%(59)$ of respondents were much better off .

Table 19: Introduced services quality improvement.

\begin{tabular}{|ll|l|l|l|l|}
\hline \multicolumn{1}{|c|}{} & & & & Fumulative \\
Valid & about the same & 11 & 7.3 & 7.3 & $\begin{array}{l}\text { Vulid Percent } \\
\text { Percent }\end{array}$ \\
& somehow better off & 66 & 44.0 & 44.0 & 7.3 \\
& much better off & 73 & 48.7 & 48.7 & 51.3 \\
& Total & 150 & 100.0 & 100.0 & 100.0 \\
\hline
\end{tabular}

According to the table19, $7.3 \%$ of respondents revealed that introduced services quality improvement was about the same, $44.0 \%$ of respondents were somehow better off and $48.7 \%$ of respondents said much better off. 
INTERNATIONAL JOURNAL OF ACADEMIC RESEARCH IN BUSINESS AND SOCIAL SCIENCES Vol. 10, No. 2, Feb, 2020, E-ISSN: 2222-6990 @ 2020 HRMARS

\section{Tests of Normality}

Table 20: Tests of Normality

\begin{tabular}{|l|l|l|l|l|l|l|}
\hline \multirow{2}{*}{} & \multicolumn{3}{l|}{ Kolmogorov-Smirnov ${ }^{\mathrm{a}}$} & \multicolumn{3}{l|}{ Shapiro-Wilk } \\
\cline { 2 - 7 } & Statistic & Df & Sig. & Statistic & df & Sig. \\
\hline Human & & & & & & \\
resource & .121 & 150 & .000 & .907 & 150 & .000 \\
Budget & .136 & 150 & .000 & .977 & 150 & .001 \\
Infrastructure & 166 & 150 & .000 & .915 & 150 & .000 \\
Performance & .084 & 150 & .012 & & 150 & .005 \\
of SMIS & & & & & & \\
\hline
\end{tabular}

a. Lilliefors Significance Correction

From normality table we can see that for Kolmogorov-Smirnovand Shapiro-Wilk test the $p$ value is exactly $0.00, .001, .000, .005$ which means the test is significant and not follows normal distribution. And also, from histogram, normal Q-Q plot and detrended normal Q-Q plot, the test statistic not follows the normal distribution.

\section{Tests of Reliability}

Table 21: Reliability Statistics

\begin{tabular}{|l|l|}
\hline Cronbach's Alpha & N of Items \\
\hline 721 & 4 \\
\hline
\end{tabular}

Here the value of Cronbach's Alpha is 0.721 which indicates the internal consistency of our data. 
INTERNATIONAL JOURNAL OF ACADEMIC RESEARCH IN BUSINESS AND SOCIAL SCIENCES

Vol. 10, No. 2, Feb, 2020, E-ISSN: 2222-6990 @ 2020 HRMARS

\section{Test of Correlations}

Table 22: Correlations

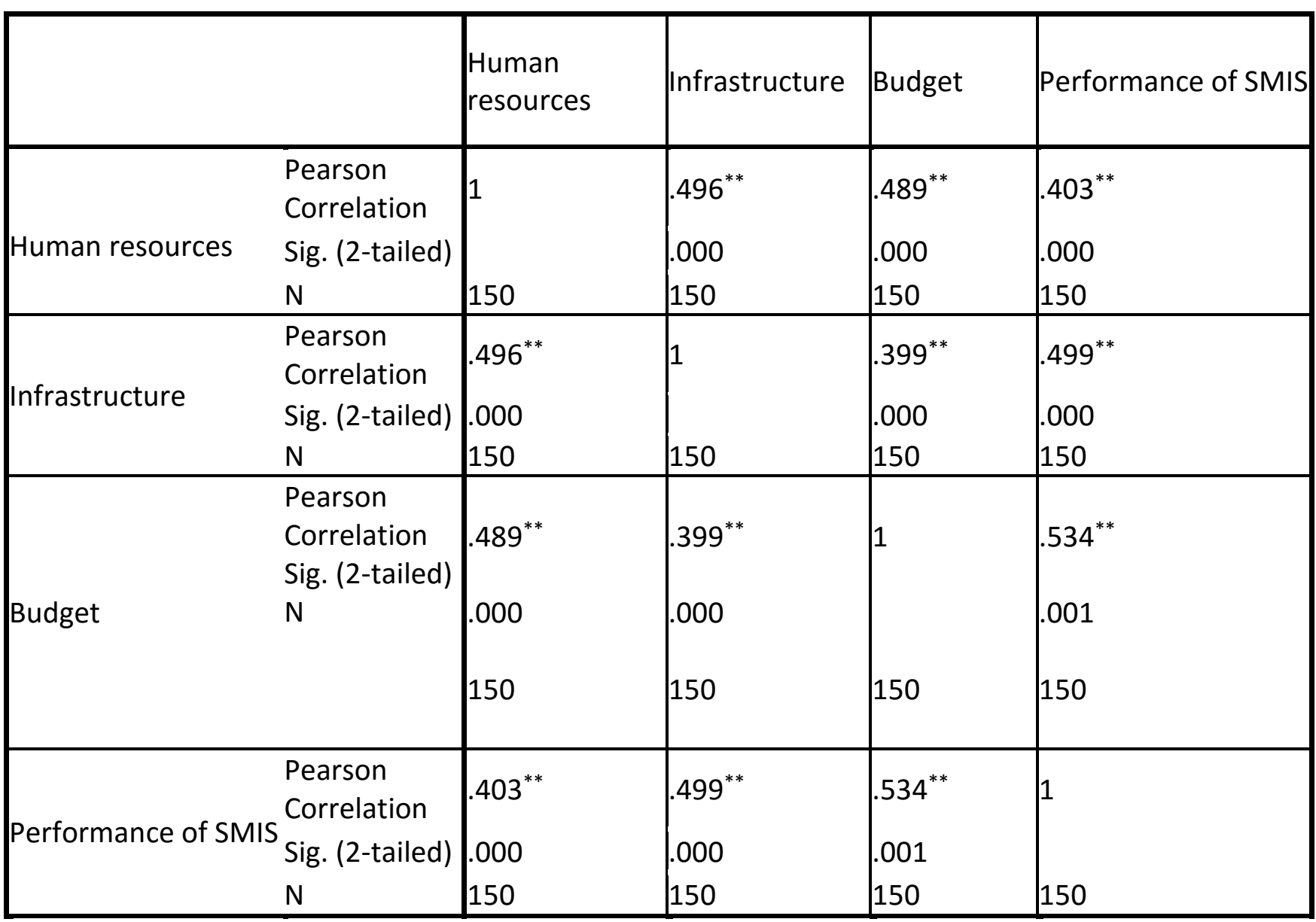

**. Correlation is significant at the 0.01 level (2tailed).

From above table we can see the value of correlation coefficient $r$. we know the values of $r$ lies between -1 to 1 . If the value is close to 1 then there exists a strong relationship between the variables. And also, if the value of $r$ closes to zero then there exist weak relation between the variables. If the value of $r$ is negative then there exists native relation between the variables.

From above table-

$>$ The relationship between the result of the Human resources and the result of Infrastructure is approximately good because the value of the coefficient is 0.496 . As the sign of the Pearson correlation coefficient is positive Table shows the correlation results which indicate that there was a positive and significant relationship. This was evidenced by the $p$ value of 0.000 which is less than that of critical value (0.05). So, there is a strong correlation between the factors.

$>$ The relationship between the Human resources and Performance of SMIS in ministry of interior is approximately good because the value of the coefficient is 0.403 . As the sign of the Pearson correlation coefficient is positive Table shows the correlation results which indicate that there was a positive and significant relationship. This was evidenced by the $p$ value of 
0.000 which is less than that of critical value (0.05). So, there is a strong correlation between the factors.

$>$ The relationship between the Budget and Performance of SMIS in ministry of interior is approximately good because the value of the coefficient is 0.534 . As the sign of the Pearson correlation coefficient is positive Table shows the correlation results which indicate that there was a positive and significant relationship. This was evidenced by the $p$ value of 0.000 which is less than that of critical value (0.05). So, there is a strong correlation between the factors.

$>$ The relationship between the result of Infrastructure and Performance of SMIS in ministry of interior is approximately good because the value of the coefficient is 0.499 . As the sign of the Pearson correlation coefficient is positive Table shows the correlation results which indicate that there was a positive and significant relationship. This was evidenced by the $p$ value of 0.000 which is less than that of critical value (0.05). So, there is a strong correlation between the factors.

\section{Conclusion}

In this turbulent era, organizations have to enhance their aggressiveness by upgrading efficiency, advancement, quality and adaptability of managements at the individual and authoritative levels. Keeping in mind the end goal to address this key test, organizations create and apply more advanced and complete MISs. Competitive advantage comes from the capability of an organization to strive in new technologies and markets where flexibility, autonomy, and experimentation are needed (O'Reilly \& Tushman, 2013; Čirjevskis, 2016). Authoritative conduct writing has put uncommon accentuation on examining information systems (IS) adequacy for a long time. This study examined the importance of three factors (Budgetary, infrastructure and Human resource). Results shows organizations cannot ignore this three factors integration into the policy to implementation.

Government policy also should encourage information infrastructure, systems planning and coordination. Success of an information system depends largely on a clear understanding of the objectives and requirements of the system. This means that IT use planning and a thorough requirements study based on an understanding of priority program needs are essential. IT use planning identifies a long-term strategy and ensures an overall consistency of information infrastructure and systems development with the main objectives and priorities of the government as a whole. Planning is the key to success and the only way to manage change effectively. Planning also brings control and leads to better resources management and priority setting. Under a long-term plan, the projects undertaken will be those most needed by the government agencies and will form an integrated set of systems that work together. Theoretically this paper provide a comprehensive overview on SMART government operating model, National plan of UAE, performance management network. The output of this study makes IT management aware about the upcoming problems and rooms for development.

\section{References}

Alshamsi, Y. A. A. B., Hock, O. Y., Karim, A. M., \& Hossain, M. I. (2019). Developing a Framework on Performance and Challenges of Strategic Management Information System: A Case study on Ministry of Interior, UAE. International Journal of Academic Research in Business and Social Sciences, 9(5), $633-646$. 
INTERNATIONAL JOURNAL OF ACADEMIC RESEARCH IN BUSINESS AND SOCIAL SCIENCES

Vol. 10, No. 2, Feb, 2020, E-ISSN: 2222-6990 ¿ 2020 HRMARS

Al-Khalifa, H. (2018). Keynote Address, Eighth GCC e-Government, Internet \& Telecommunications Forum, May 28- 29, Dubai, UAE.

AlQubaisi, F. (2017). Strategic Plan Implementation in The UAE Public Sector Organizations: Antecedents and Outcomes. Available: https://scholarworks.uaeu.ac.ae/all_theses/636

Čirjevskis, A. (2016). Sustainability in Information and Communication Technologies' industry: Innovative Ambid exterity And Dynamic Capabilities Perspectives. Journal of Security \& Sustainability Issues 6.2.

Earl, M. J. (2002). Approaches to information systems planning in Strategic Management- Challenges and Strategies in Managing Information Systems R.D.

Mahmoudi, M. (2009). Strategic management of human resources through the implementation of management information system.

O'Reilly, C., \& Tushman, M. (2013). Organizational ambidexterity: Past, Present, and Future. The Academy of Management Perspectives, 27(4), 324-338.

Willcocks, L. P., \& Lester, S. (2003). Information technology and organizational performance-Beyond the IT productivity paradox in: Strategic Information Management. 